\title{
Peranan Customer Service Dalam Meningkatkan Pelayanan Kepada Nasabah Pada PT. BPD Sumatera Barat Cabang Pasar Raya Padang
}

\author{
Putri Natasya ${ }^{1)}$, Doni Marlius ${ }^{2)}$ \\ ${ }^{1,2)}$ Akademi Keuangan dan Perbankan "Pembangunan" Padang \\ putrinatasya2711@gmail.com
}

\begin{abstract}
This study aims to know the role of customer service in improving service to customers at PT. BPD Sumatera Barat Cabang Pasar Raya Padang. In analyzing the data, the author uses qualitative data analysis methods as a research method that explains in depth the role of customer service in improving services to customers at PT. BPD Sumatera Barat Cabang Pasar Raya Padang. The method of analysis is viewed from two different aspects, namely between theory and practice. The results of the research on the role of customer service in providing information are very good and customers are very satisfied with the services provided by customer service.
\end{abstract}

Keywords: Customer Service

\section{LATAR BELAKANG}

Kondisi pada dunia perbankan yang ada di Indonesia telah mengalami perubahan dari waktu ke waktu. Kondisi perbankan saat ini mulai terganggu semenjak terjadi nya masa pandemi Covid 19. Walaupun Lembaga Penjamin Simpanan (LPS) dan Otoritas Jasa Keuangan (OJK) menyatakan kondisi perbankan saat ini relatif stabil, meski hanya harus meningkatkan kewaspadaan dan mengantisipasi dampak negatif dari Covid 19. Dalam menghadapi dampak Covid 19 tersebut maka pihak perbankan perlu mengupayakan peningkatan pelayanan terutama dalam kualitas sumber daya manusia (SDM) dalam hal pelayanan jasa customer service supaya nasabah tetap ingin menggunakan jasa pelayanan di bank tersebut.

Bank ialah lembaga keuangan yang bertugas memberikan jasa keuangan melalui simpanan (penitipan uang), kredit (peminjaman uang), serta jasa keuangan lainnya. Bank menurut UU Negara Republik Indonesia Nomor 10 Tahun 1998 Tanggal 10 November 1998 tentang Perbankan merupakan badan usaha keuangan yang kerjanya menghimpun dana masyarakat dalam bentuk simpanan dan menyalurkannya kembali dalam bentuk kredit atau bentuk lainnya dalam jangka waktu yang telah ditentukan dan telah disepakati bersama guna meningkatkan taraf hidup masyarakat banyak.

Untuk itu, bank harus dapat menjaga kepercayaan yang diberikan oleh nasabah. Secara umum, pengertian customer service ialah aktivitas yang diperuntukkan agar dapat memberikan kepuasan nasabah melalui pelayanan yang diberikan seseorang (Fernandes \& Marlius, 2018). Secara customer service memiliki 
peran yang penting dalam memberikan layanan juga sebagai pembina hubungan dengan masyarakat.

Fungsi utama dari customer service lebih cenderung kepada fungsi marketing dikarenakan unit ini merupakan jembatan penghubung antara kepentingan seorang nasabah dengan kegiatan operasional bank. Pada dasarnya customer service tidak melayani secara langsung bagian administrasi pembukuan dari transaksi financial yang dilakukan oleh nasabah, namun membantu para nasabah yang ingin berhubungan dengan bank. Di tengah kondisi persaingan yang semakin tinggi, perusahaan perbankan sebaiknya terus meningkatkan pelayanan customer service untuk mencapai kualitas kerja yang tinggi hendaknya customer service mampu untuk mengadakan interaksi personal dengan kualitas yang lebih baik mengingat kalau unit customer service ialah unit terdepan yang secara langsung berhadapan dengan calon nasabah atau nasabah (Ramadhan, 2020).

Saat ini, customer service merupakan senjata utama dalam usaha memenangkan persaingan, seiring dengan banyak nya perusahaan perbankan yang mempunyai layanan yang sama untuk diperlihatkan kepada calon nasabah atau nasabah. Pelayanan customer service yang bermutu hanya dapat dipahami dari cara pandang nasabah, yaitu seorang nasabah lebih banyak memberikan nilai terhadap tingkat pelayanan yang diberikan kepada nasabah misalnya, mencangkup prosedur dan sistem yang sudah tertata guna menyampaikan produk dan pelayanan dan bagaimana seorang penyedia pelayanan dalam menggunakan sikap, prilaku, kemampuan berbicara serta cara berinteraksi terhadap pelanggannya (Wijayanti, n.d.).

Dalam memberikan pelayanan, customer service dituntut untuk selalu memberikan pelayanan terbaik supaya dapat memuaskan nasabah tanpa melanggar harga diri dan etika dengan pelayanan tersebut maka nasabah akan merasa senang dan puas serta dihargai, sehingga nasabah akan kembali lagi untuk bekerja sama dengan perusahaan tersebut (Fernos, 2019).

Pada umumnya, permasalahan yang sering terjadi di dalam customer service yaitu pelayanannya, misalnya dalam melayani satu nasabah dibutuhkan waktu yang lama sehingga nasabah yang lain jadi tidak sabar untuk menunggu waktu antreannya, selain itu ada juga permasalahan yang sering terjadi yaitu komplain nasabah yang kurang ditanggapi dan nasabah yang selalu dioper kesana kemari tanpa kejelasan (Wijayanti, n.d.). Oleh karena itu pihak bank sebaiknya melatih staf atau tim layanan nasabah untuk lebih tanggap dan cepat dalam memberikan pelayanan termasuk merespon keluhan nasabah dan meminta maaf atas waktu yang terlalu lama, sehingga nasabah dapat memaklimunya.

PT. BPD Cabang Pasar Raya Padang sebagai salah satu lembaga keuangan yang berbasis konvensional, dalam menjalankan kegiatan usahanya selalu mengutamakan kepuasan nasabah diantaranya melayani masyarakat yang ingin menggunakan produk pendanaan, ada beberapa produk pendanaan di PT. BPD Cabang Pasar Raya Padang di antaranya Tabungan, Sertifikat Deposito, Deposito Berjangka dan Giro. 
PT. BPD Cabang Pasar Raya Padang merupakan salah satu unit perbankan di kota padang yang telah berusaha memberikan pelayanan terbaik dalam melayani nasabahnya. Maka untuk mengetahui lebih lanjut mengenai pelayanan customer service, maka peneliti tertarik untuk melakukan penelitian dalam tugas akhir yang berjudul "Peranan Customer Service dalam meningkatkan pelayanan kepada nasabah pada PT. BPD Sumatera Barat Cabang Pasar Raya Padang”.

\section{METODE PENELITIAN}

Metode penelitian yang digunakan: 1) penelitian perpustakaan yaitu penelitian ini dilakukan guna mengumpulkan data menggunakan teori-teori yang ada kaitannya dengan masalah yang akan dibahas, yang diperoleh dari sumber yang ada berupa buku-buku yang berkaitan dengan masalah yang akan dibahas. 2) penelitian lapangan yaitu dengan cara pengamatan langsung dan melakukan wawancara dengan pihak yang terkait.

Metode Analisa Data, Menurut (moleong, 2007) penulis menggunakan analisa kualitatif yang bertujuan untuk memahami fenomena tentang sesuatu yang dialami oleh subjek penelitian misalnya, persepsi, prilaku, tindakan, motivasi secara holistik dan dengan cara deskripsi dalam bentuk kata - kata dan bahasa, pada suatu konteks khusus yang alamiah dengan memanfaatkan berbagai metode alamiah. Terutama tentang peranan customer service dalam meningkatkan pelayanan kepada nasabah. Dengan metode ini penulis mencoba memberikan fakta - fakta atau kenyataan yang dialami dengan teori yang ada.

\section{HASIL DAN PEMBAHASAN Pengertian Bank}

Kata bank berasal dari bahasa Italia yaitu banca yang merupakan tempat penukaran uang. Secara umum pengertian bank ialah lembaga intermediasi keuangan yang didirikan untuk menerima simpanan serta meminjam uang, dan menerbitkan banknote (Fernandes \& Marlius, 2018).

Bank menurut (Hamidu, 2013) adalah lembaga keuangan yang aktivitas utamanya adalah menghimpun dana dari masyarakat dan menyalurkannya kembali ke masyarakat dan memberikan jasa lainnya.

Sedangkan menurut Hasibuan (2008 : 11) bank merupakan salah satu badan keuangan yang aktivitas usahanya adalah menghimpun dana dari masyarakat dalam bentuk simpanan dan menyalurkannya kepada masyarakat dalam bentuk kredit atau bentuk lainnya guna meningkatkan taraf hidup masyarakat banyak.

\section{Jenis - Jenis Bank}

Menurut (Drs. Kasmir, 2014) jenis - jenis bank terdiri dari :

1. Berdasarkan fungsinya :

a. Bank sentral

Adalah sebuah lembaga swasta yang bertanggung jawab atas kebijakan moneter pada suatu negara. 
b. Bank umum

Adalah sebuah lembaga keuangan yang tugasnya menghimpun dana dari masyarakat dalam bentuk simpanan dan menyalurkan kembali kepada masyarakat dalam bentuk kredit.

c. Bank BPR

Adalah badan usaha keuangan bank yang melaksanakan aktivitas usaha secara konvensional berdasarkan prinsip syariah yang kegiatannya tidak memiliki lalu lintas pembayaran.

2. Berdasarkan operasionalnya :

a. Bank konvensional

Merupakan bank yang melakukan aktivitas usahanya dengan cara konvensional yang memberikan jasa secara umum berdasarkan peraturan yang diterapkan suatu negara.

b. Bank syariah

Merupakan bank yang aktivitas usahanya dilakukan berdasarkan prinsip syariah atau hukum islam yang di atur dalam fatwa MUI.

3. Berdasarkan kepemilikannya :

a. Bank milik pemerintah

Adalah bank yang sebagian atau seluruh sahamnya milik pemerintah.

b. Bank milik swasta nasional

Adalah bank yang sahamnya dimiliki oleh swasta nasional beserta akta pendiriannya dimiliki oleh swasta.

c. Bank milik koperasi

Adalah bank yang pemilik sahamnya dimiliki oleh perusahaan berbadan hukum koperasi.

d. Bank milik campuran

Adalah bank yang sahamnya dimiliki pihak asing dan pihak swasta nasional.

e. Bank milik asing

Adalah bank yang memiliki cabang di indonesia yang berasal dari luar negeri.

4. Berdasarkan statusnya :

a. Bank devisa

Adalah bank yang bisa melakukan transaksi ke laur negri dan kegiatan lainnya yang ada hubungannya dengan mata uang asing.

b. Bank non devisa

Adalah bank yang juga bisa melakukan transaksi ke luar negri, akan tetapi wilayah transaksinya dibatasi dan hanya untuk negara tertentu.

5. Berdasarkan prinsipnya :

a. Bank syariah

Adalah bank yang menjalankan usahanya berdasarkan hukum islam. Menggunakan sistem bagi hasil dan penyertaan modal. 
b. Bank konvensional

Adalah badan usaha yang mencari keuntungan dengan menetapkan metode penetapan harga sesuai dengan suku bunga.

\section{Pengertian Customer Service}

Customer service secara umum yaitu aktivitas yang diperuntukkan untuk memberikan kepuasan nasabah, melalui pelayanan yang diberikannya yang bisa memenuhi kebutuhan nasabah (Fernos, 2019). Customer service memegang peran yang sangat penting di dalam dunia perbankan dikarenakan customer service berhubungan langsung dengan nasabah.

Customer Service (Khotamin \& Dahlan, 2018) mengatakan pelayanan ialah usaha untuk melayani kebutuhan orang lain. Pelayanan pada dasarnya yaitu aktivitas yang di berikan kepada konsumen yang dilayani, yang tidak dapat dimiliki dan bersifat tidak berwujud.

Sedangkan menurut Kasmir $(2003,216)$ customer service secara umum adalah kegiatan yang diperuntukan untuk memberikan kepuasan kepada nasabah, melalui pelayanan yang dapat memenuhi kebutuhan nasabah.

Seorang customer service dituntut untuk selalu bisa membangun kerja sama yang baik dengan para nasabah dan selalu memberikan pelayanan yang terbaik agar nasabah betah untuk tetap menjadi nasabah di bank tersebut. Customer service bank dalam melayani nasabahnya harus selalu berusaha untuk dapat merayu nasabah dengan cara ramah dan merayu agar mau menjadi nasabah tetap di bank tersebut.

\section{Fungsi Customer Service}

Beberapa fungsi customer service antara lain yaitu :

1. Sebagai resepsionis

Artinya customer service memiliki fungsi sebagai penerima tamu yang datang. Menerima tamu maksudnya melayani nasabah yang memiliki keperluan. Dalam hal ini customer service harus memberikan informasi selengkap mungkin dan bersikap dengan menyenangkan, ramah tamah dan sopan.

2. Sebagai deskman

Artinya seorang customer service paham dan mengerti dalam melayani nasabah dengan berbagai macam aplikasi yang diajukan oleh calon nasabah dan nasabah.

3. Sebagai salesman

Artinya customer service memiliki fungsi yaitu orang yang menjual produk. Dalam artian menawarkan produk kepada para calon nasabah yang datang. Dalam hal ini customer service harus pandai merayu dan meyakinkan nasabah hingga jadi membeli produk yang ditawarkan.

4. Sebagai customer relation officer

Artinya memiliki fungsi menjadi orang yang bisa membangun hubungan baik dengan para nasabah, termasuk membujuk agar nasabah tetap ingin bertahan. 
5. Sebagai komunikator

Artinya sebagai orang yang berkomunikasi dengan nasabah dan memberi tahukan tentang segala informasi yang ada.

\section{Pengertian Nasabah}

Nasabah adalah orang yang datang beberapa kali ke tempat yang sama guna membeli suatu barang atau peralatan. Nasabah juga dimaksud dengan pihak yang menggunakan jasa bank baik itu keperluan sendiri maupun perantara bagi keperluan pihak lain (Krisni, 2014)

Nasabah menurut pasal 1 ayat (17) UU No. 10 Tahun 1998 adalah "pihak yang menggunakan jasa bank". Nasabah memiliki peran yang penting dalam dunia perbankan, dimana dana yang disimpan di bank merupakan dana terpenting dalam operasional bank untuk menjalankan usahanya.

Menurut (Saladin, 1994)nasabah merupakan konsumen - konsumen penyedia dana. Nasabah memiliki peran penting dalam dunia perbankan, dimana dana yang disimpan di bank merupakan dana terpenting dalam operasional bank untuk menjalankan usahanya.

\section{Pengertian Pelayanan}

Pelayanan merupakan salah satu aktivitas yang diberikan produsen ke konsumen, seperti seorang customer service ke nasabahnya. Pelayanan yang baik akan menciptakan kenyamanan bagi nasabahnya yang akan menjadikan loyal terhadap bank tersebut serta tetap ingin menjadi nasabah tetap di bank tersebut.

Menurut (Amstrong \& Kotler, 2008) pelayanan adalah aktivitas atau manfaat yang ditawarkan oleh suatu pihak kepada pihak lain yang pada dasarnya tanpa wujud dan tidak menghasilkan kepemilikan apapun.

Sedangkan menurut (Mulyono, 2008) juga mendefenisikan pelayanan adalah kegiatan tambahan keluar tugas pokok (job description) yang diberikan kepada konsumen serta dirasakan baik sebagai penghormatan atau penghargaan.

\section{Pentingnya Pelayanan}

Banyak bisnis retail, terutama skala kecil yang kerap mengabaikan pelayanan yang diberikan kepada konsumen, pelayanan terhadap konsumen yang buruk dapat menghambat kelancaran bisnis karena pelayanan adalah kunci utama dalam sebuah suksesnya usaha.

Bahwa pelayanan sangat berpengaruh signifikan terhadap kepuasan pelanggan, namun pelayanan yang baik saja tidak cukup untuk memberi kepuasan kepada pelanggan (Fernandes \& Marlius, 2018).

Alasan pentingnya suatu pelayanan terhadap perusahaan antara lain :

1. Akan diingat oleh konsumen

Akan selalu diingat oleh pelanggan jika pelayanan yang diberikan sangat baik atau sangat buruk.

2. Menunjukkan kepedulian kepada pelanggan

Disaat customer service mampu memberikan pelayanan yang maksimal bagi nasabah, disitulah pihak bank menunjukkan kepedulian terhadap nasabah. 
3. Berdampak seluruh bisnis

Jika customer service memberikan pelayanan yang baik, orang akan secara natural berasumsi produk yang dijual memiliki kualitas yang baik.

4. Strategi marketing yang baik

Salah satu strategi marketing dalam meningkatkan penjualan ialah meningkatkan pelayanannya.

5. Menarik pelanggan baru

Dengan pelayanan yang baik diberikan maka nasabah akan menceritakan kepada temannya yang lain sehingga bank berpeluang untuk mendapatkan nasabah baru.

\section{Peranan Customer Service dalam Meningkatkan Pelayanan kepada Nasabah di PT. BPD Cabang Pasar Raya Padang}

Peranan Customer Service dalam meningkatkan pelayanan kepada nasabah di PT. BPD Cabang Pasar Raya Padang adalah kunci sukses dan dasar untuk membangun keberhasilan bank tersebut.

Pada dasarnya Customer Service memiliki peran yang sangat penting di PT. BPD Cabang Pasar Raya Padang. Di dalam dunia perbankan tugas utama seorang Customer Service yaitu memberikan pelayanan yang terbaik untuk mendapatkan kepuasan nasabah. Customer Service di PT. BPDaerah Cabang Pasar Raya Padang di dalam melayani nasabahnya selalu berusaha menarik nasabah dengan cara meyakinkan bahwa bank tersebut dapat memberikan pelayanan dan menawarkan berbagai jasa dan produk supaya nasabah tertarik untuk menjadi nasabah tetap di bank tersebut.

Oleh karena itu, segala kegiatan yang dilakukan harus dengan baik, sopan, ramah dan profesional agar mendapat kepuasan nasabah. Kepuasan nasabah tersebut dapat mempengaruhi suksesnya bank tersebut karena nasabah akan menjadi loyal terhadap bank tersebut. Selain itu dengan kepuasan nasabah tersebut nasabah dapat merekomendasikan bank tersebut kepada teman, rekan kerja, atau keluarga untuk menjadi calon nasabah baru di bank tersebut.

Peranan Customer Service dalam meningkatkan pelayanan terhadap nasabahnya di PT. BPD Cabang Pasar Raya Padang dapat dilihat sebagai berikut :

1. Selalu fokus kepada produk - produk yang ada di bank nagari

2. Bisa mempertahankan nasabah lama agar tetap menjalin hubungan baik dengan bank nagari melalui pembinaan hubungan yang akrab

3. Mengenali apa yang dibutuhkan oleh seorang nasabah dan menyampaikannya dengan sikap yang positif

4. Berusaha untuk mendapatkan nasabah baru dengan cara berbagai pendekatan melalui pemberitahuan bahwa produk yang ada di bank nagari berkualitas

5. Membantu nasabah dalam pembukaan dan penutupan rekening di bank nagari

Dasar dari pelayanan yang harus dikuasai oleh seorang customer service sebelum melakukan tugasnya, mengingat karakter masing - masing nasabah sangat beragam. 
Di dalam manajemen perbankan, ada beberapa dasar - dasar pelayanan yang harus dipahami oleh seorang customer service yaitu sebagai berikut :

1. Berpenampilan dan berpakaian yang rapi dan bersih

Harus menggunakan pakaian yang cocok dengan kombinasi yang menarik. Pakaian yang dipakai oleh seorang customer service harus dapat memikat konsumen.

2. Percaya diri, penuh senyum dan bersikap akrab

Dalam melayani nasabah seorang customer service tidak boleh ragu - ragu, harus dengan rasa percaya diri yang tinggi supaya nasabah tertarik dengan produk yang ditawarkan. Di dalam setiap pelayanan customer service harus senyum agar nasabah merasa betah dan nyaman.

3. Menyapa dengan ramah dan berusaha menyebutkan nama nasabah

Pada saat nasabah datang, customer service harus menyapa nasabah terlebih dahulu, usahakan menyebutkan nama dalam menyapa nasabah agar lebih akrab.

4. Tenang, hormat, sopan tekun dalam mendengarkan setiap pembicaraan

Bersikap tenang tidak terburu - buru dan penuh hormat terhadap nasabah yang ingin melakukan keluhannya seorang customer service harus mendengarkannya dengan baik.

5. Tekun di dalam mendengarkan pembicaraan dan menerima keluhan dengan baik

Seorang customer service harus bisa menerima setiap keluhan yang dikeluhkan oleh nasabah, dapat mendengarkannya dengan baik. Sehingga hal tersebut dapat membuat nasabah merasa dihargai.

6. Berbicara jelas dengan bahasa yang baik dan benar

Menggunakan Bahasa Indonesia, dengan suara yang digunakan jelas dan mudah dipahami.

7. Bergairah dalam melayani dan tunjukan kemampuan

Customer service harus memperlihatkan pelayanan yang baik dengan memahami keinginan dan kemauan nasabah.

8. Jangan memotong atau menyela pembicaraan

Jangan menyela jika nasabah sedang berbicara, hindari kata yang bersifat sindiran dan jangan berdebat dengan nasabah jika terjadi sesuatu.

9. Mampu menyakinkan nasabah serta memberikan kepuasan

Customer service harus mampu meyakinkan nasabah dengan produk yang ditawarkan berkualitas.

10. Jika tidak bisa menangani masalah yang ada, mintalah bantuan

Dalam melayani nasabah ada hal yang tidak bisa kita selesaikan sendiri, maka dari itu mintalah bantuan kepada yang sanggup untuk menangani nasabah tersebut. 
11. Jika belum bisa melayani, beritahu kapan nasabah akan dilayani

Jika pada saat nasabah datang seorang customer service sedang sibuk dan tidak dapat diganggu, maka beritahu kepada nasabah kapan ia akan dilayani dengan simpatik.

Adapun faktor utama yang mendukung pelayanan di perbankan yaitu, sumber daya manusia (customer service) yang melayani langsung nasabah secara transparan dan terbuka.

Ciri - ciri pelayanan yang baik bagi seorang customer service terhadap nasabahnya yaitu :

1. Sarana fisik, maksudnya tersedianya perlengkapan dan jumlah karyawan yang memadai.

2. Tanggung jawab, maksudnya memerikan pelayanan yang bertanggung jawab sejak awal.

3. Responsif, maksudnya mampu melayani secara tepat dan cepat.

4. Komunikatif, maksud nya menjelaskan dengan penjelasan yang mudah dimengerti.

5. Kredibilitas, maksudnya kepercayaan public kepada pegawainya.

6. Keamanan, maksudnya terjaminnya keamanan untuk bertransaksi.

7. Keramahan, maksudnya ramah dengan cara bersikap yang baik.

8. Pemahaman, maksudnya berusaha memahami kebutuhan public.

9. Hubungan, maksudnya kemudahan berhubungan dengan melakukan kontak dengan pegawai.

Seorang customer service bisa mengangkat nama baik perusahaan dengan pelayanan yang diberikannya. Terkadang nasabah selalu melakukan hal - hal yang bisa memberikan rasa puas terhadap diri mereka sendiri, misalnya dengan prosedur yang mereka inginkan tidak sesuai.

Menjaga perasaan nasabah supaya nasabah merasa tenang dan nyaman menjadi nasabah di PT. BPD Cabang Pasar Raya Padang sangatlah penting dimana customer service merupakan garda terdepan dalam kemajuan suatu perusahaan.

PT. BPD Cabang Pasar Raya Padang memberikan kenyamanan kepada calon nasabah maupun nasabah. Untuk memenuhi kebutuhan calon nasabah ataupun nasabah bank pada PT. BPD Cabang Pasar Raya Padang membuat unit yang juga menjadi sarana komunikasi dan pemasaran bagi bank yaitu customer service atau pelayanan pelanggan.

Customer service adalah salah satu bagian dari unit organisasi yang berada paling depan di dalam bank yang memiliki fungsi sebagai sumber informasi dan perantara bagi bank dan nasabah yang mau mendapatkan jasa pelayanan maupun produk yang ada di bank. Dengan komunikasi yang baik ini akan membangun hubungan kerja sama dengan calon nasabah atau nasabah dan menjaga hubungan itu tetap baik.

Hal ini tentu harus dilakukan guna menjaga hubungan tetap baik, juga berarti tetap menjaga citra baik perusahaan. Diantara customer service dengan nasabah akan 
berinteraksi langsung dan disini akan terjadi saling tukar menukar pesan antara customer service dengan nasabah sehingga terjalin hubungan yang sangat akrab.

Tanpa komunikasi yang dilakukan khususnya oleh customer service, nasabah secara keseluruhan tidak akan mengetahui keberadaan produk bank tersebut. Oleh karena itu customer service juga berperan sebagai penjual produk dari bank, menawarkan kepada nasabah produk bank dari PT. BPD Cabang Pasar Raya Padang tersebut. Peran customer service terhadap nasabah dalam proses transaksi, pra transaksi, maupun pasca transaksi. Oleh karena itu customer service dituntut harus mempunyai kemampuan melayani nasabah secara baik, tepat, cepat dan tanggap, serta memiliki kemampuan berbahasa yang baik, melakukan pembiacaraan dengan kata sopan hindari bentakan dan sindiriran, demi mencapai kepuasan nasabah.

Peranan customer service juga merupakan suatu sumber daya manusia yang diperlukan oleh suatu perusahaan dalam melakukan pelayanan. Peranan ini mempunyai hubungan secara langsung dengan nasabah, maka sangat perlu customer service yang pandai dan handal dalam memikat nasabah. Arti dari customer service secara umum yaitu kegiatan yang diperuntukan agar dapat memberikan kepuasan kepada nasabah, lewat pelayanan yang bisa memenuhi keinginan nasabah.

Customer service itu ibaratkan wajah terdepan pada sebuah bank. Seorang customer service bisa menyelesaikan masalah dan keluhan, serta mampu menjelaskan berbagai macam produk dan informasi bank dengan detail. Cara customer service melayani nasabah mencerminkan bagaimana sesungguhnya sikap bank tersebut. Sehingga baik buruknya pelayanan akan terpengaruh dengan persepsi dan loyalitas nasabah terhadap bank tersebut.

Ada beberapa faktor yang bisa mempengaruhi loyalitas nasabah, antara lain yaitu kepuasan, kepercayaan, dan komitmen dari nasabah tersebut. Hal ini disebabkan karena mempertahankan nasabah berarti juga mempertahankan kelangsungan hidup bank tersebut.loyalitas berasal dari kata dasar "loyal" yang berarti setia, atau suatu kesetiaan.

Oleh karena itu, untuk antisipasi dalam persaingan yang semakin ketat dengan perbankan lainnya maka pihak bank perlu menciptakan hubungan yang baik dengan para nasabah, baik nasabah yang lama ataupun yang baru. Untuk menciptakan loyalitas nasabah khususnya penabung disini yang merupakan salah satu pertahanan berlangsungnya sebuah bank.

Jadi nasabah penabung ini menitipkan sebagian dana yang dimilikinya untuk diolah oleh bank yang bersangkutan dan dengan cara menabung nasabah akan merasa aman. Semakin memadai atau lengkap jasa yang diterima oleh nasabah tersebut maka akan sebaik, demikian pula sebaliknya jika jasa bank yang diberikan kurang lengkap atau kurang memadai, maka nasabah terpaksa untuk mencari bank lain.

Dengan adanya hubungan yang baik tersebut maka akan menarik perhatian dan minat masyarakat untuk menjadi nasabah di bank. Akan tetapi tumbuhnya minat masyarakat akan menabung atau menggunkan jasa bank tersebut tidak bisa muncul dengan sendirinya jika di hati masyarakat tersebut tidak terdapat kepuasan. 


\section{SIMPULAN}

Berdasarkan hasil analisis yang telah dilakukan pada bab sebelumnnya, maka dapat ambil kesimpulan sebagai berikut :

1. Customer Service adalah aktivitas yang diperuntukan untuk memberikan kepuasan nasabah, melalui pelayanan yang diberikannya yang bisa memenuhi kebutuhan nasabah.

2. Customer Service selalu dituntut untuk selalu bisa membangun kerjasama yang baik dengan nasabah dan selalu bisa memberikan pelayanan yang baik agar nasabah betah untuk tetap menjadi nasabah di bank nagari cabang pasar raya.

3. Dalam memberikan pelayanan yang baik, bank telah menetapkan standar yang didukung sarana dan prasarana yang ada sehingga kepuasan nasabah dapat terpenuhi. Kepuasan tersebut dapat tergantung dengan kenyamanan yang diberikan customer service kepada nasabahnya.

4. Nasabah adalah seseorang atau badan usaha yang memiliki rekening simpanan atau pinjaman dan dapat melakukan transaksi simpanan atau pinjaman pada bank tersebut. Sedangkan Pelayanan adalah suatu kegiatan yang dilakukan seseorang untuk memenuhi kepuasan nasabah dalam mencapai tujuan perusahaan.

5. Alasan mengapa pentingnya suatu pelayanan terhadap nasabah yaitu :

a. Akan diingat selalu oleh konsumen

b. Menunjukkan kepedulian kepada pelanggan

c. Berdampak kepada seluruh bisnis

d. Strategi marketing yang baik

e. Menarik pelanggan baru

6. Pada dasarnya customer service memegang peranan yang sangat penting di PT. BPD Cabang Pasar Raya Padang. Salah satu tugas utama seorang customer service yaitu memberikan pelayanan yang terbaik untuk mendapatkan kepuasan nasabah.

\section{UCAPAN TERIMAKASIH}

Dengan menyebut nama Allah SWT yang Maha Pengasih lagi Maha Penyayang, penulis ucapkan puji dan syukur atas kehadirat-Nya, yang telah melimpahkan rahmat, hidayah-Nya kepada saya. Penulis ingin menyampaikan terimakasih kepada pimpinan PT. BPD Sumatera Barat Cabang Pasar Raya Padang atas izin penelitiannya.

\section{DAFTAR PUSTAKA}

Amstrong, G., \& Kotler, P. (2008). Prinsip-prinsip Pemasaran, Edisi ke-12. Jakarta: Erlangga.

Fernandes, Y. D., \& Marlius, D. (2018). Peranan Customer Service Dalam Meningkatkan Pelayanan Kepada Nasabah Pada Pt. Bank Pembangunan Daerah Sumatera Barat Cabang Utama Padang. 1-12. 
https://doi.org/10.31227/osf.io/wrh3p

Fernos, J. (2019). Peranan Customer Service Dalam Meningkatkan Pelayanan Terhadap Nasabah Pada Bank Nagari Cabang Siteba Padang. 1-8. https://doi.org/10.31227/osf.io/cq458

Hamidu, N. P. (2013). Pengaruh kinerja keuangan terhadap pertumbuhan laba pada perbankan di BEI. Jurnal EMBA: Jurnal Riset Ekonomi, Manajemen, Bisnis Dan Akuntansi, 1(3).

Khotamin, N. A., \& Dahlan, R. (2018). Implementasi Service Excellence Oleh Customer Service Pada Bpr Syari'ah Way Kanan. Khozana, 1(1), 96-127.

Marlius, D., \& Nurfazila, N. (2020). Aktivitas Pemasaran Tabungan Pada Pt. Bank Pembangunan Daerah Sumatera Barat Cabang Pembantu Tarusan. https://doi.org/10.31219/osf.io/fvqc7

Mulyono, B. H. (2008). Analisis Pengaruh Kualitas Produk Dan Kualitas Layanan Terhadap Kepuasan Konsumen (Studi Kasus Pada Perumahan Puri Mediterania Semarang). program Pascasarjana Universitas Diponegoro.

Ramadhan, S. (2020). Peranan Customer Service Dalam Pelayanan Produk pada Bank Sumsel Babel Cabang Pembantu KM 12 Laporan Akhir.

Saladin, D. (1994). Dasar-Dasar Manajemen Pemasaran Bank. Jakarta: Mandiri Маји.

Susanti. F, Marlius, D, Kahirumi. S. (2021). Customer Satisfication Pada Pembelian Smartphone Samsung Dilihat Dari Trust In Brand, Brand Image Dan Word Of Mouth Di Sarana Smartphone Kota Solok. Jurnal Pundi. Volume 5. No. 1. Hal. 1-20. Sekolah Tinggi Ilmu Ekonomi KBP. Padang.

Wijayanti, N. (n.d.). Peran Customer Service Dalam Meningkatkan Pelayanan pada Bank Lampung Cabang Bandar Jaya. 